\title{
The Effect of Emotional Intelligence on Maternity Role
}

\section{Duygusal Zekânın Annelik Rolüne Etkisi}

\author{
Betül MAMMADOV ${ }^{1} \mathbb{D}$, Ayten ȘENTÜRK ERENEL ${ }^{2}$ \\ ${ }^{1}$ Department of Midwifery, Near East University Health Sciences Faculty, Nicosia, Cyprus \\ ${ }^{2}$ Department of Obstetrics and Gynecology Nursing, Gazi University Nursing Faculty, Ankara, Turkey
}

ORCID ID: Betül Mammadov 0000-0002-9051-0279, Ayten Șentürk Erenel 0000-0002-0841-2099

Cite this article as: Mammadov B and Șentürk Erenel A. The Effect of Emotional Intelligence on Maternity Role. Med J West Black Sea. 2021;5(2):150-155.

Corresponding Author

Betül Mammadov

E-mail

betul.mammadov@neu.edu.tr

Received

14.11.2020

Revision

06.01.2021

Accepted

29.01.2021

\begin{abstract}
Aim: The relationship between emotion and intelligence is among the philosophical issues that have been discussed throughout human history. Scientists, who discovered that managing emotions has an important role in the success of people in personal and business life, developed the concept of 'emotional intelligence' and added emotional intelligence; they defined emotions as an ability to understand and to deal with emotions. This research was conducted to evaluate the relationship between the emotional intelligence of mothers and their motherhood role.
\end{abstract}

Material and Methods: 211 women who applied to the University Hospital Maternity Service and outpatient clinics were interviewed using "Personal Information Form", "Schutte Self-Report Emotional Intelligence Test" (SSEIT) and "Semantic Difference Scale-I as Mother".

Results: The average age of women was $35.7 \pm 8.9 .47 .9 \%$ had undergraduate and above education, $62.1 \%$ were employed and $85.8 \%$ had social security coverage. A significant correlation was found between the Schutte Self-Report Emotional Intelligence Test Scale $(144.14 \pm 18.122)$ and the Semantic Difference Scale-I as Mother scale $(61.53 \pm 9.100)$ scores $(p=0.001)$. In addition, the maternity role scores increased significantly with the age $(p=0.009)$. Emotional Intelligence scores were significantly associated with an increased level of education $(p=0.001)$. At the same time, Emotional Intelligence scores were higher in women who had social security $(p=0.001)$.

Conclusion: Our study showed that mothers with high emotional intelligence find themselves more successful in performing their motherhood role.

Keywords: Emotion, Intelligence, Emotional intelligence, Pregnancy, Maternity, Maternity role

öz

Amaç: Duygu ve zekâ arasındaki ilişki, insanlık tarihi boyunca tartışılan felsefi meselelerden biridir. Duyguları yönetmenin, insanların kişisel ve iş hayatındaki başarısında önemli bir rol oynadığını keşfeden bilim adamları, 'duygusal zekâ' kavramını geliştirdiler ve duygusal zekâ kavramını duyguları anlama ve duygularla başa çıkma yeteneği olarak tanımladılar. Bu araştırma, annelerin duygusal zekâsı ile annelik rolleri arasındaki ilişkiyi değerlendirmek amacıyla yapılmıştır.

Gereç ve Yöntemler: Üniversite Hastanesi Doğum Servisi ve Polikliniklerine başvuran 211 kadınla "Kişisel Bilgi Formu", "Schutte Duygusal Zekâ Testi” (SDZÖ) ve "Anne Olarak Ben - Anlamsal Farklılık Ölçeği” ile anket yapılmıştır.

Bulgular: Kadınların yaş ortalaması $35.7 \pm 8.9$ idi ve $\%$ 47,9'u lisans üstü eğitime,\% 62,1'i bir işe ve\% $85,8$ 'i sosyal güvenceye sahipti. Schutte Duygusal Zekâ Testi Ölçeği (144.14 \pm 18.122$)$ ile Anne Olarak Ben-Anlamsal Farklılık Ölçeği $(61.53 \pm 9.100)$ puanları arasında anlamlı bir iliş̧ki bulunmuştur $(p=0.001)$. Ayrıca annelik rolü puanları yaşla birlikte anlamlı olarak artmıştır $(p=0.009)$. Duygusal Zekâ puanları, artan eğitim düzeyi ile anlamlı derecede ilişkiliydi $(p=0.001)$. Aynı zamanda, sosyal güvencesi olan kadınlarda Duygusal Zekâ puanları daha yüksekti $(p=0.001)$.

Sonuç: Çalışmamız duygusal zekâsı yüksek annelerin annelik rollerini yerine getirmede kendilerini daha başarılı bulduklarını göstermiştir.

Anahtar Sözcükler: Duygu, Zekâ, Duygusal zekâ, Gebelik, Annelik, Annelik rolü 


\section{INTRODUCTION}

Feelings are defined as the impulses that initiate differences in life and facilitate life, enable us to act, and occur with physiological changes and behaviors in feelings and mental attitudes. Feelings play a guiding or evaluative role in providing energy for the person to take action and meet their own needs, controlling the environment or performing appropriate behaviors to meet these needs (1). The relationship between emotion and intelligence is among the philosophical issues discussed throughout the history of humanity. In the classical approach, making decisions that are not affected by emotions is the ideal way of thinking. In modern approaches, the absolute sovereignty of mind to emotions has begun to be questioned $(2,3)$. When the relationship between emotion and intelligence is examined from a sociological perspective, we encounter the fact that emotional and rational processes act together. The concepts of IQ (cognitive intelligence), which is the measure of the mind, and EQ (emotional intelligence), the measure of emotions, are the concepts that reinforce and complement each other. Scientists, who discovered that managing emotions has an important role in the success of people in personal and business life, developed the concept of 'emotional intelligence' and tried to define this concept $(4,5)$. Emotional intelligence; emotions are defined as the ability to understand the relationship between emotions and to solve problems. IQ does not only ensure human success in life. It is stated that emotional intelligence is more important than classical intelligence. It has been suggested that combining $I Q$ and $E Q$ would be more useful in order to increase vital efficiency. The knowledge that the effective and correct use of emotional intelligence adds to personal life and thus social life cannot be ignored (6-8).

Transition to motherhood is one of the important processes in women's life. Having a baby in the family life cycle is considered to be a difficult period because it is a happy event for the mother and father, as well as a change that requires new roles and responsibilities. Acting as a motherhood and parenting role is a very complex and multi-stage challenging process. Maternal role acquisition is a process that starts with determination of pregnancy, develops during pregnancy, continues in the postpartum period, and is completed with the formation of maternal identity development, that is, motherhood (9). The shaping of motherhood identity occurs with every child born, and it takes place in four phases: expectations phase, formal phase, informal phase, and personal phase. Each of these stages are affected by the relationship between the mother and father, family function, important people, stress and social support. It is important for mothers to prepare for the transition to new roles in the prenatal and postnatal period so that they can play a successful maternity role. This research was conducted to evaluate how and to what extent mothers used their emotional intelligence in maternity role (10-12).

\section{MATERIALS and METHODS}

The study was conducted on 211 women who applied to the University Hospital Maternity Service and outpatient clinics using "Personal Information Form", " Schutte SelfReport Emotional Intelligence Test" (SSEIT) and "Semantic Difference Scale-I as Mother".

Before starting to collect the research data, the necessary permissions were obtained from the ethics committee and the hospital directorate. The Personal Information Form was created by the researcher and consisted of a total of 17 questions examining the sociodemographic and obstetric characteristics of pregnant women.

\section{Schutte Self-Report Emotional Intelligence Test (SSEIT)}

This scale was developed in 1998 by Schutte, Malouff, Hall, Haggerty, Cooper, Golden and Dornheim. It was reorganized in 2004 by Saklofske, Huang and McKenney as 41 items. The Schutte emotional intelligence scale was adapted to Turkish in 2011 by Tatar et al. In this study, the Cronbach-Alpha internal consistency coefficient of the scale adapted to Turkish was found to be 0.82 . The scale has three sub-dimensions. These dimensions are optimism / regulation of mood is defined as the use of emotions and the evaluation of emotions. In accordance with the scale of the scale, $1=$ Definitely Agree and $5=$ Absolutely Disagree was applied with a five-point Likert-type answer option. In this scale, the highest score was calculated as 205 and the lowest score was 41. (13).

\section{Semantic Difference Scale- Myself as Mother (MMS)}

The scale was developed by Walker (Walker et al., 1986) in 1982 and the Turkish validity and reliability study was conducted by Calisir in 2003. $(14,15)$. The scale measures the evaluation dimensions of the concept of "Myself as Mother". It consists of 11 semantic pairs of 11 adjectives with eleven items and 7 points. Three items were evaluated with reverse scoring in order to prevent the participant from being biased when responding. The third, seventh, and eighth items were evaluated on a "1" score instead of a "7" score. High total scores obtained from the scale show positive motherhood self-assessment. The scale has the lowest 11 points and the highest 77 points. Cronbach Alpha reliability coefficient of the scale was determined as .73-.74.

\section{Data Analysis}

The data were evaluated using the SPSS 20.0 package program. Percentages, averages, analysis of variance, correlation coefficient, $t$ test, Kruskal Wallis were used to evaluate the obtained data. The t-test was used to 
compare the Emotional Intelligence Scale scores and sociodemographic characteristics, since the data fit the normal distribution. The Kruskal Wallis test was used to compare Maternity Role scores, which did not conform to normal distribution, and sociodemographic characteristics.

\section{RESULTS}

The average age of women participating in the study ( $\mathrm{n}$ $=211$ ) was $35.7 \pm 8.9 .47 .9 \%$ had undergraduate and postgraduate education, $62.1 \%$ were employed. $85.8 \%$ had social security and $63 \%$ had income that was equal to expenses and $37 \%$ of them resided in the rural areas (Table 1). This women are $55.9 \%$ had more than one child, $19.4 \%$ had broad families, and $5.7 \%$ were divorced. The last pregnancy of $8.5 \%$ was unplanned. $33.1 \%$ had more than one abortion history.

While the mean scores the participants got from the "Emotional Intelligence Scale" was 144.14 \pm 18.122 , the average of the points they got from the "Myself as Mother" was $61.53 \pm 9.100$.

A significant correlation was found between the scores that the women got from the Emotional Intelligence Scale (144.14 \pm 18.122$)$ and the scores they got from the Myself as Mother Scale $(61.53 \pm 9.100)(p=0.001)$. It was found that women with high emotional intelligence had high maternal role scores.

As the age of women increased, their Maternity Role scores increased significantly ( $p=0.009$ ). Emotional Intelligence scores were associated with an increased level of education ( $p=0.001$ ). It was also found that Emotional Intelligence score was higher in women who had social security ( $p$ $=0.008)$ (Table 2).

Emotional Intelligence Scale scores were not significantly correlated with age ( $p=0.380)$, working status ( $p=0.086)$, family structure $(p=0.065)$, income-expense status ( $p$ $=0.098)$, place of residence $(p=0.136)$, total number of pregnancies ( $p=0.863$ ), number of abortions ( $p=0.388$ ), number of living children ( $p=0.244)$, and planned pregnancy $(p=0.670)$.

The scores obtained from the "Myself as Mother" were not significantly correlated with education ( $p=0.556)$, working status $(p=0.143)$, family structure $(p=0.508)$, incomeexpense status $(p=0.130)$, place of residence $(p=0.619)$, social security $(p=0.570)$, total pregnancy number $(p$ $=0.305)$, number of abortions ( $p=0.137)$, number of living children ( $p=0.545)$, and planned pregnancy $(p=0.097)$.

\section{DISCUSSION}

The mean total score of the mothers' emotional intelligence scale in our study was found to be $144.14 \pm 18.112$. The highest score that can be obtained from the emotional intelligence scale is 205, and the high scores indicate high emotional intelligence. According to these findings, we can say that the emotional intelligence levels of the women participating in the study were at a medium level. We could not find any study investigating the effect of

Table 1: Demographic and obstetric characteristics of women

\begin{tabular}{|c|c|}
\hline Sociodemographic Features & $\mathrm{n}=211(\%)$ \\
\hline \multicolumn{2}{|l|}{ Age } \\
\hline 24 years old and under & $15(7.1)$ \\
\hline Between 25-40 years old & $138(65.4)$ \\
\hline 41 and over & $58(27.5)$ \\
\hline \multicolumn{2}{|l|}{ Education } \\
\hline Primary education & $46(21.8)$ \\
\hline High school & $64(30.3)$ \\
\hline Undergraduate education & $82(38.9)$ \\
\hline Postgraduate education & $19(9.0)$ \\
\hline \multicolumn{2}{|l|}{ Place of Residence } \\
\hline City & $86(40.8)$ \\
\hline County & $47(22.2)$ \\
\hline Village & $78(37.0)$ \\
\hline \multicolumn{2}{|l|}{ Employment Status } \\
\hline Employed & $131(62.1)$ \\
\hline Unemployed & $80(37.9)$ \\
\hline \multicolumn{2}{|l|}{ Income Status } \\
\hline Negative income balance & $54(25.6)$ \\
\hline Neutral income balance & $133(63.0)$ \\
\hline Positive income balance & $24(11.4)$ \\
\hline \multicolumn{2}{|l|}{ Social Security } \\
\hline Yes & $181(85.8)$ \\
\hline No & $30(14.2)$ \\
\hline \multicolumn{2}{|l|}{ Number of Pregnancies } \\
\hline 1 & $64(30.3)$ \\
\hline 2 & $80(37.9)$ \\
\hline 3 & $39(18.5)$ \\
\hline 4 and more & $28(13.2)$ \\
\hline \multicolumn{2}{|l|}{ Number of living children } \\
\hline 1 & $93(44.1)$ \\
\hline 2 & $89(42.2)$ \\
\hline 3 & $22(10.4)$ \\
\hline 4 and more & 7 (3.3) \\
\hline \multicolumn{2}{|l|}{ Stillbirth-Abortion } \\
\hline 0 & $141(66.8)$ \\
\hline 1 & $49(23.2)$ \\
\hline 2 & $15(7.2)$ \\
\hline 3 and more & $6(2.8)$ \\
\hline
\end{tabular}


Table 2: Comparison of the "Schutte Emotional Intelligence Rating Scale" and "Myself as Mother" scores with the demographic characteristics

\begin{tabular}{|c|c|c|c|c|}
\hline & $\begin{array}{l}\text { Schutte Emotional Intelligence Rating } \\
\text { Scale Mean } \pm \text { std. dev (t-test) }\end{array}$ & $\mathbf{p}$ & $\begin{array}{l}\text { Myself as Mother Median (min-max) } \\
\text { (Kruskal Wallis) }\end{array}$ & $\mathbf{p}$ \\
\hline \multicolumn{5}{|l|}{ Education Status } \\
\hline Primary education & $134.41 \pm 14.595$ & \multirow{4}{*}{0.001} & $62.00(42-77)$ & \multirow{4}{*}{0.556} \\
\hline High school & $141.14 \pm 16.054$ & & $64.00(28-74)$ & \\
\hline Undergraduate & $149.12 \pm 18.495$ & & $63.00(41-77)$ & \\
\hline Postgraduate & $152.53 \pm 20.681$ & & $65.00(50-73)$ & \\
\hline \multicolumn{5}{|l|}{ Employment Status } \\
\hline Employed & $141.41 \pm 17.754$ & \multirow{2}{*}{0.086} & $64.00(40-77)$ & \multirow{2}{*}{0.143} \\
\hline Unemployed & $145.80 \pm 18.210$ & & $62.00(28-77)$ & \\
\hline \multicolumn{5}{|l|}{ Income Status } \\
\hline Negative income balance & $139.63 \pm 18.692$ & \multirow{3}{*}{0.098} & $61.00(40-77)$ & \multirow{3}{*}{0.130} \\
\hline Neutral income balance & $145.46 \pm 17.375$ & & $63.00(28-77)$ & \\
\hline Positive income balance & $146.96 \pm 19.868$ & & $65.00(50-72)$ & \\
\hline \multicolumn{5}{|l|}{ Social Security* } \\
\hline Yes & $145.48 \pm 17.689$ & \multirow{2}{*}{0.008} & $63.00(28-77)$ & \multirow{2}{*}{0.570} \\
\hline No & $136.07 \pm 18.908$ & & $61.00(45-77)$ & \\
\hline \multicolumn{5}{|l|}{ Number of living children } \\
\hline 1 & $146.55 \pm 20.668$ & \multirow{4}{*}{0.244} & $63.00(41-77)$ & \multirow{4}{*}{0.545} \\
\hline 2 & $142.73 \pm 15.929$ & & $64.00(44-77)$ & \\
\hline 3 & $139.55 \pm 12.262$ & & $62.00(48-74)$ & \\
\hline 4 and more & $141.33 \pm 22.591$ & & $55.00(28-75)$ & \\
\hline
\end{tabular}

emotional intelligence on the role of motherhood although there are different studies showing that women's emotional intelligence levels are higher than men $(16,17)$. It is thought that the reason for the higher emotional intelligence of women is due to the fact that the woman has a more emotional nature and the hormones secreted during the motherhood increase the emotional behavior. The emotional intelligence score averages were higher in women with high educational status and possessing a social security coverage. Some studies found that emotional intelligence scale scores increased when the education levels of families and students increased $(16,18)$. It is a known fact that academic success is independent of emotional intelligence. Nevertheless, it should not be forgotten that emotional intelligence can be improved with education.

The maternal role score average of the mothers participating in the study on the scale of 'Myself as Mother' was found to be $61.53 \pm 9.10$. The high total scores obtained from the scale show positive maternal self-assessment and the highest score is "77". Considering these results, we can say that the participants obtained high motherhood role scores. In our study, it was found that there was a direct proportion between maternal age and maternal role scores. The maternal role scores obtained by the mothers with higher age were higher compared to younger mothers. Higher maternal age positively contributes to parental behavior. It is known that the age of having children in terms of physical and psychological health of the mother and baby is between the ages of 20-35. In addition, these are the ages when the mother is the healthiest, energetic and productive. There are studies showing that the process of achieving motherhood role by a woman is affected by her personality structure, age, education status, health status, attachment to the child, self-concept, relationship with the child's father, parenting education, quality of marriage relationship, child care and support systems (19-23).

Some studies have concluded that young mothers are not able to use verbal communication methods compared to older mothers since they have not yet completed their developmental maturity (24-26). In our study, we found that there was no difference in maternal role scores among primiparous and multiparous women. Contrary to our study, it was found that the mothers with more children had higher role scores. $(27,28)$. It has been observed that women who have experienced the maternity before benefited from their previous experiences and had less contradictions 
in establishing discipline. Comparing the scores of the mothers on the Emotional Intelligence Scale (SSEIT) and the scores on the "Myself as Mother" scale, we found that as the emotional intelligence levels of the women increased, their maternal role scores also increased. People with high emotional intelligence have high academic success, can deal with stress more easily, have more problem-solving skills, and have improved communication skills. Also, the relationship between emotional intelligence and prenatal attachment levels of pregnant women was examined, and it was found that high emotional intelligence increased the level of attachment to the fetus in the prenatal period (2932).

It is known that individuals with high level of emotional intelligence are aware of their feelings and thoughts, are successful in achieving their goals, have improved empathy skills, are optimistic and try again when they fail, and are successful in resolving interpersonal conflicts. As a result, we think that emotional intelligence is an effective factor for women in performing their motherhood roles.

Studies show that emotional intelligence is more important than cognitive intelligence in ensuring people's success and happiness. Our study showed that women with high emotional intelligence succeeded in the role of mothering better. It should not be forgotten that there are emotions that are suppressed and out of control at the basis of many physical and psychological diseases. It is important that the emotional intelligence of mothers should be high to raise both mentally and physically healthy generations. It is possible to learn the concepts we need at every time of life such as empathy, understanding emotions, coping with problems, and solving problems. Emotional intelligence can be strengthened through education programs and guidance. These trainings can be added to the prenatal mother education programs and may contribute to the development of the emotional intelligence of the mothers.

\section{Acknowledgment}

We thank all the women who participated in the study.

\section{Author Contrubitons}

Planning of the study: Ayten Şentürk Erenel, Betül Mammadov, Data collection: Betül Mammadov, Introduction Betül Mammadov, Results: Betül Mammadov, Discussion and Conclusion: Betül Mammadov, Ayten Şentürk Erenel.

\section{Conflicts of Interest}

The authors did not declare any conflict of interest related to this article.

Financial Support

None.
Ethical Approval

It was received from Near East University. (Decision No: YDU/2015/33-234)

\section{Review Process}

Extremely reviewed and accepted

\section{REFERENCES}

1. Kring AM, Johnson SI. Abnormal Psychology-The science and treatment of psychological disorders. 14th ed. Wiley LooseLeaf Print Edition; 2018. 30-31.

2. Mount, G.J. What role does emotional intelligence (EQ), Play for superior performans in the international business of a capitalintensive, asset-based industry? Organizational development. Unpublished PhD Thesis, Benedictine University, USA; 2000.

3. Mayer JD, Salovey P \& Caruso DR. Emotional intelligence as zeitgeist, as personality and as a mental ability. Handbook of, Emotional Intelligence, Jossey-Bass: California; 2000. 92-117.

4. Massey DS. A brief history of human society: The origin and role of emotion in social life. American Sociological Review 2002;(67): 1-29.

5. Lam LT, Kirby SL. Is emotional intelligence an advantage? An exploration of the impact of emotion a land general intelligence on individual performance. The Journal of Social Psychology 2002;142 (1): 133-143.

6. Mayer JD, Caruso DR, Salovey P. Emotional intelligence meets traditional standards for an intelligence. Intelligence 1999;27(4):267-298.

7. Bass BM, Bass R. The bass handbook of leadership: Theory, research, and managerial applications. 4th ed. Free Press; 2009. 67-69.

8. Salovey P, Brackett MA, Mayer JD. Emotional intelligence: Key readings on the Mayer and Salovey Model. Dude Publishing 2004:1-27.

9. Emmanuel E, Creedy DK, St John W, Gamble J \& Brown C. Maternal role development following childbirth among Australian women. J Adv Nurs 2008;64(1): 18-26.

10. Meighan M, Ramona T. Mercer: Maternal role attainmentbecoming a mother. Tomey AM, \& Alligood MR. Nursing theorists and their work. 6th ed. Mosby; 2006. 581-597.

11. Mercer R. Nursing support of the process of becoming a mother. JOGNN 2006;35(5):649-651.

12. Mercer RT. Becoming a mother versus maternal role attainment. J Nurs Scholarship 2004;36 (3): 226-232.

13. Tatar A, Tok S, Saltukoğlu G. Gözden geçirilmiş Schutte duygusal zeka ölçeğinin Türkçe'ye uyarlanması ve psikometrik özelliklerin incelenmesi. Klinik Psikofarmakoloji Bülteni 2011;21 (4): 325-338.

14. Walker LO, Crain H, Thompson E. Mothering behavior and maternal role attainment during the postpartum period. Nursing Research 1986;(35):352-355.

15. Calisir, H. Investigation of the factors affecting the maternity role attainment of primiparas. Unpublished doctoral thesis, Institute of Health Sciences, Ege University, Izmir, Turkey; 2003. 
16. Kubilay S. Duygusal zekanızı keşfedin, Truva Yayıncılık; İstanbul; 2006. 86-88.

17. Brodberry T,Greaves J. Emotional intelligence: Talent Smart; 2012. 129-176.

18. Kuzu A, Eker F. Hemşirelik öğrencilerinin duygusal zeka ve iletişim becerilerinin diğer üniversite öğrencileri ile karşılaştırmalı olarak değerlendirilmesi. Hemşirelikte Araştırma Geliştirme Dergisi 2010; (12)3: 14-29.

19. Harrod NR, Scheer SD. An exploration of adalescant emotional intelligence in relation to demographic characteristic. Adolescence 2005;40(159): 503-512.

20. Tarkka MT, Paunonen M, Laippala P. First time mothers and childcare when the child is 8 month sold, Journal of Advanced Nursing 2000;31(1): 20-26.

21. Tarkka MT, Paunonen M. Social support provided by public health nurses and the coping of first-time mothers with childcare. Public Health Nursing 1999;16(2): 114-119.

22. Murray S, Mc Kinney E, Holub K, Jones R. Foundations of maternal-newborn and women's health nursing. 7th ed. Elsevier Health Science; 2017. 124-125.

23. Wong DL, Hackenberry EM. Wong's essential of pediatric nursing. Mosby comp. 6th ed. St Louis, Baltimore; 2001. 234235.

24. Clemmens D. The relationship between social support and adolescent mothers' interactions with their infants: A metaanalysis, JOGNN 2001;30: 410-420.
25. Deihl K. Adolescent mothers; what produces positive mother -infant interaction, Maternal-Child Nursing Journal 1997;22: 89-95.

26. Walker LO, Crain H, Thompson E. Maternal role attainment and identity in the postpartum period: Stability and change. Nursing Research 1986;35(2): 68-71.

27. Grace JT. Mothers' self-reports of parenthood across the first 6 months postpartum. Research in Nursing and Health 1993; 16:431-439.

28. Balcı S, Savaşer S. Annelerin bebeklerini algılama durumu, VI. Ulusal Hemşirelik Kongresi Kongre Kitabı. Damla matbaacılık, Ankara; 1998: 215-221.

29. Deniz M, Yılmaz E. Üniversite öğrencilerinde duygusal zeka ve stresle başa çıkma stilleri arasındaki ilişkinin incelenmesi. Türk Psikolojik Danışma ve Rehberlik Dergisi 2006;3 (25):17-26.

30. İşmen AE. Duygusal zeka ve problem çözme. Marmara Üniversitesi, Atatürk Eğitim Fakültesi Eğitim Bilimleri Dergisi 2001; (13):111-124.

31. Çetinkaya Ö, Alparslan AM. Duygusal zekanın iletişim becerileri üzerine etkisi: Üniversite öğrencileri üzerinde bir araştırma. Süleyman Demirel Üniversitesi İktisadi ve İdari Bilimler Fakültesi Dergisi 2011;16 (1):363-377.

32. Buko G, Özkan H. Gebelerin duygusal zekaları ile prenatal bağlanma düzeyleri arasındaki ilişki. Anadolu Hemşirelik ve Sağlık Bilimleri Dergisi 2016; 9 (4): 217-224. 